\title{
ABA Signal Transduction Pathway in Plants: ABA Transport, Perception, Signaling and Post-Translational Modification
}

\author{
Jae-Hoon Lee*
}

\author{
Department of Biology Education, Pusan National University, Busan 609-735, Korea
}

Received December 11, 2013 /Revised December 27, 2013 /Accepted December 30, 2013

\begin{abstract}
During the life cycle of plants, water deficit leads to an adverse effect on its growth and development. To increase the productivity of crops, overcoming such drought stress is one of the most important issues in the field of plant study. Among plant hormones, the phytohormone, abscisic acid (ABA) plays a crucial role in eliciting resistance to drought stress as well as in multiple developmental processes, such as seed germination, stomatal closure, and seedling growth. Therefore, further understanding of the ABA-mediated signal transduction pathway in plants is an effective strategy to generate drought-tolerant plants. Posttranslational modification, such as phosphorylation and ubiquitination, is an efficient mechanism for plants to acquire quick adaptation against environmental stress conditions since this process directly affects pre-existing signaling components by modulating protein activity and stability. Here, recent reports on ABA signaling are reviewed, especially focusing on ABA transport, perception, signaling, and posttranslational modification in ABA-mediated cellular responses. Also, we present future prospects on how the control of such a mechanism can be applied to generate useful agricultural crops.
\end{abstract}

Key words : Abscisic acid, drought stress, post-translational modification, signaling, transport

\section{서 론}

세계기상기구(WMO)의 보고에 따르면, 환경의 변화, 인구 의 증가 등으로 인해 2025년까지 세계 인구 중 약 6억 9억명 이, 2050년까지 약 24억명이 물부족을 겪을 것으로 예상되고 있다. 이러한 물부족 현상은 농업 측면에서도 심각한 문제를 초래할 것으로 보이는데, 실제로 가뭄 스트레스(drought stress)는 전세계 농경지의 약 $50 \%$ 에 해당하는 지역의 작물 생산성에 직접적인 영향을 미치고 있으며, 작물의 생산량을 감소시키는 주요한 스트레스로서 지목되어 오고 있다[5]. 그러 므로, 환경 스트레스(abiotic stress)에 대한 식물의 대응 기작 을 연구하는 식물학자들에게 있어서, 이러한 가뭄 스트레스 저항성 기작을 상세히 규명하는 것은 최근 들어 가장 주목을 끌고 있는 연구 주제 중 하나이다. 식물 호르몬 중 앱시스산 (abscisic acid)은 식물의 가뭄 스트레스에 대한 저항성을 확립 하기 위하여 주된 역할을 하는 호르몬으로서, 그 산업적 연구 가치를 높이 평가 받아 온 호르몬이다. 앱시스산은 가뭄저항 성 외에도 식물의 대사과정중 씨앗의 발아(seed germination),

\footnotetext{
*Corresponding author

Tel : +82-51-510-2700, Fax : +82-51-514-8576

E-mail : jhlee72@pusan.ac.kr

This is an Open-Access article distributed under the terms of the Creative Commons Attribution Non-Commercial License (http://creativecommons.org/licenses/by-nc/3.0) which permits unrestricted non-commercial use, distribution, and reproduction in any medium, provided the original work is properly cited
}

휴면(seed dormancy), 기공의 개폐(stomata closure), 유묘의 생장(seedling growth), 물부족 스트레스(drought stress) 과정 에 있어 중요한 조절 역할을 담당한다 $[13,24]$.

앱시스산의 신호 전달 기작은 다른 호르몬과 비교할 때 최 근에 들어서야 비로소 구체적인 정립이 이루어지고 있다. 이 는 앱시스산 신호 전달에 관여하는 신호 전달 단백질들의 다 양한 보고에 의해 세포 내부에서의 전달 과정에 대한 규명은 비교적 상세하게 이루어져 왔음에도 불구하고, 2009년 이전까 지 해당 신호 전달 과정을 개시하는 주 수용체에 대한 규명이 이루어지지 않았기 때문이다. 이전에 보고된 앱시스산 수용체 의 경우 그 역할이 대단히 한정적이거나 다른 연구그룹들간의 상충되는 연구 결과로 인해 전체 신호 전달 과정을 설명하기 에는 미흡한 실정이었다. 2009년 이후 PYR/PYL/RCAR (Pyrabactin Resistant/PYR-Like/Regulatory Component of ABA Receptors) 수용성 수용체 그룹의 분리로부터 기존에 알 려져 있던 PP2C (Protein Phosphatase 2C), SnRK2s (SNF1RELATED PROTEIN KINASE 2s), bZIP 타입의 전사조절인 자로 이어지는 앱시스산 경로의 상위를 비로소 연결시킬 수 있게 되었으며, 이는 해당 호르몬 신호 전달 과정의 많은 부분 을 설명할 수 있도록 공헌하였다[19, 23, 26, 80]. 이러한 진전에 도 불구하고, 앱시스산 반응 유전자 발현을 조절하는 다수의 전사 조절 인자(AREB/ABF/ABI5, AtMYC2, ABI3, ABI4 등) 의 활성 조절에 관한 연구 및 그 하위단계 유전자들의 역할 및 기능에 대한 구체적 연구는 상당부분 미흡한 상태로 남아 있는데, 이는 앱시스산 신호 경로와 관련되어 아직도 많은 풀 
어야 할 숙제가 남아있음을 의미한다.

앞서 언급한 바와 같이 식물은 물부족 스트레스에 대한 대 응을 위하여, 관련 조절 시스템의 많은 부분을 앱시스산의 증 가를 통한 신호전달 과정을 통해 구축해 왔다. 이러한 대응과 정에 있어서, 조절과정에 필요한 단백질을 해당 전사체의 증 가를 통해 축적하는 것보다(transcriptional regulation), 이미 축적되어 있는 관련 단백질을 빠른 시간 내에 변형시키는 것 이 자극에 대한 신속한 반응을 위해 효율적일 것이다. 이에 최근 들어 앱시스산에 의해 매개되는 세포 내 반응에서, 단백 질의 번역 후 변형과정(post-translational modification)을 통 해 이루어지는 부분을 이해하고자 하는 연구 접근이 급격히 증가하고 있는 실정이다. 본 총설에서는 최근까지 업데이트된 식물의 앱시스산에 의한 세포 내 반응 기작을 앱시스산의 수 송, 인지, 신호전달 측면에서 접근하여 탐색하고자 한다. 또한, 해당 신호 전달에 관여하는 신호전달 단백질의 조절 기작을, 그들의 활성 및 안정화에 영향을 미치는 번역 후 변형과정에 초점을 맞추어 알아보고자 한다. 이는 앱시스산에 대한 보다 상세한 이해를 통해 물부족 스트레스에 의한 피해를 최소화 할 수 있는 방안 제시에 도움이 될 것이라 사료된다.

\section{본 론}

\section{앱시스산 수용체}

호르몬 연구에 있어서 가장 출발점이 되는 부분은 세포 내 에서 해당 호르몬을 처음으로 인지하는 수용체에 대한 동정 및 상세규명이라 할 수 있는데, 다른 식물 호르몬과 비교하여 앱시스산의 수용체는 오랜 기간 동안 명확히 규명되지 못했 다. 이는 해당 수용체가 다수의 유전자족(gene family)으로 존 재함으로써 생기는 기능적 중복성(functional redundancy)에 기인하거나 혹은 상기 수용체의 돌연변이가 개체의 치사 (lethality)를 유래하기 때문일 것으로 예상되어 왔다[49]. 이에 기존의 호르몬 수용체를 분리하기 위하여 주로 사용되었던 순유전학(forward genetics) 기법과는 다른 전략을 통해 $\mathrm{ABA}$ 수용체를 분리하고자 하는 노력이 진행되어 왔으며, 그 결과 최근 들어 서로 다른 종류의 몇 가지 수용체가 분리되었다.

앱시스산 수용체로 보고된 첫번째 단백질은 $\mathrm{ChlH}(\mathrm{Mg}$ chelatase H subunit) 단백질로서 잠두(Vicia faba)로부터 친화 크로마토그래피(affinity chromatography)를 이용하여 분리 되었으며, 이후 애기장대에서 보고된 상동 단백질인 $\mathrm{ChlH} /$ ABAR (Abscisic Acid Receptor)/CCH (Conditional Chlorina)/ GUN5 (Genome Uncoupled 5)가 실제로 앱시스산과 관계된 세포내 다양한 반응에 실질적으로 관여함이 밝혀졌다[74, 83, 89]. 흥미롭게도 이들의 세포 내 위치는 엽록체막(chloroplast envelope)로 밝혀졌는데, 이러한 사실을 통해 해당 소기관막 에 위치하는 이들이 어떻게 $\mathrm{ABA}$ 신호를 전달할 수 있는지에 대한 궁금증이 대두되었다. Zhang 그룹은 특정 WRKY그룹의
단백질(WRKY40 등)이 $\mathrm{ABI} 5, \mathrm{DREB} 2 \mathrm{~A}$ 와 같은 앱시스산 반응 유전자의 발현을 억제하며, 이들 전사 조절인자가 앱시스산 존재 시 발생하는 $\mathrm{ChlH}$ 의 핵에서 세포질로의 격리(sequester) 에 관여함으로써 해당 반응을 가능케 함을 제시하였다[72]. 그 럼에도 불구하고, 보리의 $\mathrm{ChlH}$ 상동 단백질은 앱시스산에 실 제로 결합하지 않으며, 애기장대의 WRKY40 돌연변이체가 $\mathrm{ABA}$ 과다 감수성 및 $\mathrm{ABI}$, DREB2A의 전사 촉진을 유발하지 않는다는 상충된 보고들은 $\mathrm{ChlH}$ 그룹이 실제 $\mathrm{ABA}$ 수용체로 서의 생체 내 역할을 수행하고 있음을 명확히 하기에 어렵도 록 하고 있다[6, 52].

$\mathrm{G}$ 단백질 연계 수용체(G protein-coupled receptor, GPCR) 와 상동성을 보유하였으나, 기능적 차별성을 갖는 새로운 형 태의 막단백질인 GTG1 (GPCR-type G proteins 1), GTG2 단 백질이 또다른 잠재적인 앱시스산 수용체로서 보고되었다 [64]. 이들은 기존의 GPCR과는 달리 자체적으로 GDP/GTP 결합 활성과 GTP 분해 효소(GTPase) 활성을 보유하고 있으 며, 이종삼량체 G 단백질의 $a$-소단위체(heterotrimeric G-protein $a$-subunit)와 결합할 수 있다. 앱시스산과의 결합은 GDP 와의 결합형태에서 더 강하게 나타나는 것을 볼 수 있는데, 이는 GTP보다는 GDP와의 결합이 앱시스산 신호 전달 과정을 위해 요구됨을 보여준다. 이들의 이중 돌연변이체인 gtg1gtg2 가 앱시스산 반응성의 완전한 소실을 보이지 못하고 감소된 앱시스산 반응성을 보이는 것은, 또다른 앱시스산 인식 기작 이 존재하고 있음을 보여준다. 또한 이들이 9개의 막통과 도메 인을 갖는 전형적인 $\mathrm{G}$ 단백질 연계 수용체에 비해 단지 7개의 막통과 도메인을 보유하고 있다는 사실은 해당 단백질의 독특 한 세포 내 역할을 암시하고 있다.

앞서 기술한 바와 같이 앱시스산 신호 전달 분야의 급격한 진전을 이루는 새로운 수용체의 존재가 합성 앱시스산 경쟁자 (agonist)인 pyrabactin에 불감성을 가지는 돌연변이체인 pyr1 으로부터 2009년에 밝혀졌다[66]. 해당 산물인 PYR1은 START/ Bet v I 거대 유전자족에 속하는 것으로 알려졌다. 비슷한 시기 에, 초기 앱시스산 반응에 중요한 역할을 하는 탈인산화 효소 2C (Protein Phosphatase 2C, PP2C)인 ABI2와 HAB1 (HOMOLOGY TO ABI1)를 이용한 효모이중잡종 분석법(yeast two hybrid)으로부터 상호 구조적 유사성을 보이는 RCAR1 및 PYL5, PYL6, PYL8을 분리하였으며, ABI1 복합체 결합 단백질 분리법으로부터 상기 RCAR/PYL 그룹에 속한 일련의 9개 단 백질(PYR1, PYL1, PYL4, PYL5, PYL6, PYL7, PYL8, PYL9, PYL10)을 선별하였다. 유전체 (genome) 분석결과 이들은 애기 장대 내에 총 14 개의 유전자족으로 구성되어 있음이 확인되었 다. 이들이 앱시스산과 결합할 수 있고, 앱시스산에 의한 탈인 산화 효소 $2 \mathrm{C}$ 의 조절에 관여하고 있음을 통해 PYR/PYL/ $\mathrm{RCAR}$ 그룹의 앱시스산 수용체로 최종 분류되었다 $[47,59,70]$. 다양한 유전학 연구는 앱시스산 신호 전달 기작에서 이들이 주요한 역할을 수행함을 강력하게 보여주고 있다. 일례로 
pyr1pyl1pyl2pyl4 4중 돌연변이체(quadruple mutant)의 경우 강력한 앱시스산 불감성(씨앗의 발아, 기공 개폐, 유묘의 뿌리 생장, SnRK2에 의한 전사 발현의 변화 등과 관련하여)을 보여 주고 있으며, pyr1pyl1pyl2pyl1ppyl5pyl8 6중 돌연변이체의 경우 야생종에서는 발아가 되지 않는 조건인 $100 \mu \mathrm{M}$ 의 앱시스산 존재 하에서도 발아가 가능한 강력한 앱시스산 불감성을 보이 는데, 이는 기존에 보고된 앱시스산 신호 전달 물질 및 하위 단계 반응과 해당 그룹의 앱시스산 수용체가 기능적으로 연계 되어 있음을 제시한다[22, 59]. 또한 해당 단백질 그룹이 앞서 말한 $\mathrm{ABA}$ 반응의 초기 단계에서 중요한 역할을 하는 탈인산 화 효소 $2 \mathrm{C}$ 그룹의 단백질(ABI1, $\mathrm{ABI} 2, \mathrm{HAB1}$ 등)과 직접적인 결합을 이루고 있다는 점에서, PYR/PYL/RCAR을 통해 매개 되는 신호 전달 기작이 세포 내 앱시스산 반응 경로의 주요한 축을 구성하고 있음을 보여준다. 구조적, 생화학적 분석을 통 해 PYR/PYL/RCAR 그룹의 단백질은 이량화(dimerization) 를 이루어 작용함을 알 수 있으며, 이중 한 subunit으로의 앱시 스산 결합은 이량체(dimer)의 분리를 유발하는 것으로 보인 다. 그 결과 야기된 구조 변화가 $\mathrm{ABI} 1, \mathrm{ABI} 2$ 등의 결합을 위한 부위 노출을 야기하게 되며, PYR/PYL/RCAR와 $\mathrm{PP} 2 \mathrm{C}$ 간의 결합은 $\mathrm{PP} 2 \mathrm{C}$ 로부터 억제되던 $\mathrm{SnRK} 2$ 의 유리를 촉진함으로써 $\mathrm{ABA}$ 매개 반응을 개시하게 된다 [58, 59, 70, 84] (Fig. 1). 최근 의 연구는 pyr1pyl1pyl2pyl44중 돌연변이체가 죽은 숙주조직 에서 자라는 곰팡이(necrotrophic fungus)에 저항성을 보임을 보여주는데, 이는 살리실산/자스몬산/에틸렌(SA/ JA/ET)에 의해 매개되는 저항성 과정에 앱시스산 신호 과정이 음성적으 로 관여할 수 있음을 암시한다[69].

\section{앱시스산 수송}

상기 기술한 PYR/PYL/RCAR 앱시스산 수용체들은 수용 성 단백질로서 세포내에 위치 (세포질/핵)한다 $[47,66]$. 또한 앱시스산의 주합성 장소는 유관속 조직인데 반하여, 주된 역 할을 하는 주요 세포 중 하나는 이와 멀리 떨어져 있는 공변세 포(guard cell)인데, 이러한 결과는 세포간의 효율적 커뮤니케 이션을 위해 세포 내/외로 앱시스산을 운반하는 별도의 기작 이 필요함을 암시한다[62]. 최근 들어 원형질막에 존재하는 $\mathrm{ABC}$ (ATP-binding cassette) 타입 수송체인 ABCG25, ABCG 40 이 앱시스산 수송에 관여함이 돌연변이체 스크리닝(screening) 과정을 통해 보고되었다[27, 34]. ABCG25의 경우 식물의 기관 내 물질 운송을 담당하는 조직인 유관속 조직(vascular tissue)의 원형질막에서 주로 발현되며, 앱시스산 합성 세포에 서 ATP 의존적으로 앱시스산을 배출하는데 중요한 역할을 하는 유출운반체로서 기능한다. 해당 유전자가 결여된 $a b c g 25$ 돌연변이체는 $\mathrm{ABA}$ 에 과다감수성을 보이며, 공변세포로의 앱 시스산 전달에 결함을 야기한다. 그에 반하여 아포플라스트 (apoplast)로부터 세포질로의 앱시스산 유입은 ABCG40에 의 해 매개됨이 보고되었다. $a b c g 40$ 돌연변이체의 경우 앱시스산
존재 시 가공닫힘이 감소되고 물부족 저항성이 떨어지는 형질 을 보이는데, 해당 돌연변이체에서 앱시스산 반응 유전자의 발현 감소가 공변세포 이외에서도 발견되는 것으로 보아 $\mathrm{ABCG} 40$ 은 공변세포 이외에서도 그 기능을 수행할 것으로 예 상된다 $[24,30]$. 또다른 형태의 $\mathrm{ABC}$ 타입 수송체인 $\mathrm{ABCG} 22$ 는 아직 세부 기작이 명확히 알려져 있지 않다. 그러나, 해당 기능 소실 돌연변이체가 증가된 수분 소실을 통해 보다 민감한 가 뭄 스트레스 저항성을 보이며, 앱시스산 신호 전달 돌연변이 체인 $s r k 2 e / o s t 1$ 및 앱시스산 합성 돌연변이체인 $n c e d B$ 과의 이 중 돌연변이시에 증가된 앱시스산 결여 형질을 보임에 근거할 때, $\mathrm{ABCG} 22$ 가 앱시스산 수송과 관계하여 잠재적 역할을 수행 할 수 있음이 기대된다[35].

\section{탈인산화 효소 $2 \mathrm{C}$}

1990년대 중반에, 돌연변이체 스크리닝의 결과 앱시스산 신 호전달 기작 규명에 중요한 지평을 연, 두가지의 돌연변이체 인 $a b i 1$ 과 $a b i 2$ 가 발견되었다 $[40,50]$. 해당 유전자 산물인 ABI1 (ABA-INSENSTIVE 1)과 $\mathrm{ABI}$ 는 하위그룹(subgroup) $\mathrm{A}$ 에 해당하는 탈인산화 효소 $2 \mathrm{C}$ (protein phosphatase $2 \mathrm{C}$ )임이 밝 혀졌으며, 해당 돌연변이체인 abi1-1과 abi2-1은 전반적인 앱시 스산 반응의 비감수성을 부여하는 것으로 확인되었다[41]. 그 러나 이후 분리된 다수의 해당 유전자 기능상실 돌연변이체 (loss-of-function mutant)의 경우 오히려 앱시스산에 대한 과 다 감수성을 보이는 것으로 알려졌는데, 이는 abi1-1과 abi2-1 이 우성 음성 돌연변이체(dominant-negative mutant)임을 보 여준다 할 수 있다. $a b i 1-1$ 과 $a b i 2-1$ 은 각각 180번째와 168번째 의 글라이신(glycine)이 아스파르트산(aspartic acid)으로 변이 된 돌연변이체로서, 오랜 기간 동안 이들의 dominant negative 형질이 어떻게 부여되는지는 알려지지 않고 있었는데, 앞서 기술한 PYR/PYL/RCAR 단백질의 분리를 통해, 해당 아미노산의 돌연변이가 ABI1/ABI2와 PYR/PYL/RCAR간의 결합을 방해함이 알려지면서 이러한 의문은 비로소 풀리게 되었다[47, 66]. 또한 PYR1의 88번째 프롤린(proline)의 세린 (serine)으로의 변이 및 152번째 세린(serine)의 류신(leucine) 으로의 변이는 탈인산화 효소 $2 \mathrm{C}$ 그룹 단백질 중 하나인 $\mathrm{HAB1}$ 의 탈인산화 활성 억제를 불가하게 만드는 결과를 초래 하였는데, 상기 결과들을 종합하여 볼 때 $\mathrm{ABA}$ 와 PYR/PYL/ $\mathrm{RCAR}$ 수용체 간의 결합은 수용체-탈인산화 효소 $2 \mathrm{C}$ 간의 결 합 유발 및 탈인산화 효소 $2 \mathrm{C}$ 활성 억제를 유발함을 알 수 있다[66] (Fig. 1). 앱시스산 신호에 관여하는 탈인산화 효소 $2 \mathrm{C}$ 그룹의 단백질들은 다수가 알려져 왔다. 앞서 언급한 ABI1, $\mathrm{ABI} 2, \mathrm{HAB} 1$ 와 이에 높은 상동성을 보이는 $\mathrm{HAB} 2$, 유전적 스 크리닝 방법을 통해 선별된 AHG1 (ABA-HYPERSENSITIVE GERMINATION 1), AHG3 등이 그들인데, 이들은 상기 신호 전달 과정에서 기능적 중복성을 보이는 것 이외에도 조직 특 이적 발현을 통해 각 조직에서 특이적인 기능을 하는 것으로 
보인다[33, 60,87]. 일례로 $A B I 1$ 이 다양한 조직에서 발현되며 대부분의 조직에서 기능하는 것과 달리, $A H G$ 유전자들은 씨 에서 특이적으로 발현되어 그 역할을 수행한다[50,60,87]. 이 러한 특이적 기능은 세포 내에서의 위치 차이에 의해서도 유 추될 수 있다. $\mathrm{AHG} 1$ 및 $\mathrm{AHG} 3$ 의 경우 단지 핵 내에 존재하여 기능하는 반면, $\mathrm{ABI} 1$ 은 세포질과 핵 내에서 모두 발견되는데, 이는 공변세포에서의 단시간 내에 이루어지는 앱시스산의 반 응(세포막을 경계로 이루어지는 이온 흐름의 변화)에 관여하 는 것으로 보고된 $\mathrm{ABI} 1$ 의 세포질내 추가적인 역할과 맥락을 같이 한다[81].

\section{SnRK2 인산화 효소}

애기장대는 3 개의 하위 클래스로 분류되는 10 종류의 SnRK2 인산화 효소(sucrose non-fermenting-1 related protein kinase 2, SnRK2)를 보유하고 있다. 이중에서 하위 클래스 III 에는 3종류의 SnRK2인 SRK2D/SnRK2.2 (이하 SnRK2.2), SRK2I/SnRK2.3 (이하 SnRK2.3), OST1 (OPEN STOMATA1)/ SnRK2.6/SRK2E (이하 SnRK2.6)가 속해있으며, 이들이 ABI1 으로 대표되는 탈인산화 효소 $2 \mathrm{C}$ 단백질들과 직접적인 결합을 이룰 수 있음이 보고되었다 [18, 86]. 또한 야생종에서 앱시스산 에 의해 증가되는 SnRK2 인산화 효소의 활성이 abi1-1하에서 는 일어나지 않는 결과를 보였으며, 상기 탈인산화효소가 in vitro 상에서 SnRK2.2, SnRK2.3, SnRK2.6의 탈인산화를 직접 적으로 촉진하고 그러한 탈인산화 부위가 SnRK2 인산화 효소 의 비활성화에 직접적으로 영향을 미침이 관찰되었는데, 이는 두 그룹의 단백질들이 기능적으로 연계되어 있음을 보여준다 $[81,86]$. 그렇다면 3종류의 SnRK2가 실제로 앱시스산 신호전 달 과정에서 어떠한 세부 역할을 수행하는가? 이는 각각의 기 능소실 돌연변이체 및 2 중, 3 중 돌연변이체를 통해 확인할 수 있다. SnRK2.6의 기능 소실 돌연변이체의 경우 공변세포에서 의 앱시스산에 대한 감수성 감소와 가뭄저항성 감소의 성질을 보였으나, 유묘의 뿌리 성장과 발아과정에는 별 영향을 미치 지 않았다[85]. 반면 SnRK2.2, SnRK2.3의 단일 기능소실 돌연 변이체는 가뭄저항성에 영향을 미치지 않았으며, 2 중 돌연변 이체의 경우 종자 휴면(seed dormancy)의 감소와 유묘의 초기 유묘(seedling) 성장시 앱시스산에 대한 비감수성을 초래했다 [16]. 이는 앱시스산에 의한 가뭄저항성 과정에 있어 SnRK2.6 가, 앱시스산에 의한 초기 발생 과정에서는 SnRK2.2, SnRK2.3 가 보다 더 중요한 역할을 하는 양성 조절자임을 암시한다. SnRK2.2, SnRK2.3, SnRK2.6이 모두 결여된 3중 돌연변이체는 단일, 2중 돌연변이체에 비해 가뭄스트레스 대한 과도한 민감 성을 보였으며, 실리크(silique) 내에서의 모체발아(vivipary) 및 씨 발생 과정의 심각한 결함 형질을 나타내었는데, 이는 해당 3 종의 유전자가 앱시스산에 의해 매개되는 세포 내 다양 한 이벤트(event)에서 중요한 역할을 협동적으로 하고 있음을 암시한다 $[18,56]$. 세 종류의 인산화 효소가 어떠한 방식으로
앱시스산 신호를 전달하는지는 하위단계에서 그들과 결합하 여 인산화되는 bZIP 전사조절인자들과 연관되어 보다 상세히 설명되어질 수 있는데, 이는 아래에서 자세히 기술하고자 한 다[28]. 이와 별개로, SnRK2는 기공세포에서 이루어지는 원형 질막, 액포막의 이온 흐름 변화에도 관여하는 것으로 알려져 있다. SnRK2.6의 기질 중 하나로 알려진 SLAC1 (SLOW ANION CHANNEL-ASSOCIATED 1)은 기공 닫힘시에 요구 되는 원형질막의 탈분극화를 유발하는 음이온 통로(anion channel)로 보고되었는데, SnRK2.6에 의한 인산화가 SLAC1 을 통한 이온의 움직임에 영향을 미치는 것으로 보인다 $[7,39$, 82]. 공변세포의 $\mathrm{K}^{+}$수송체인 KAT1 역시 SnRK2.6과 직접 결 합하며 해당 단백질의 인산화에 의해 음성적으로 조절되는데, SnRK2에 의해 매개되는 이러한 이온수송체 활성 조절은 해당 인산화 효소가 상대적으로 장시간에 의해 매개되는 세포내 반응(앱시스산 수용체-탈인산화 효소 2C-SnRK2 인산화 효소 -bZIP 전사조절인자에 의해 이루어지는) 뿐 아니라 공변세포 에서 앱시스산에 의해 매개되는 빠른 세포 내 반응에도 관여 하고 있음을 보여준다[71].

\section{bZIP (basic leucine zipper) 전사조절인자 활성에 관여 하는 인산화/탈인산화}

앱시스산에 의해 전사량이 증가하는 앱시스산 반응 유전자 들의 프로모터 분석 결과, 이러한 증가에 관여하는 일련의 cisacting element들이 발견되었는데, 그 중에서 앱시스산에 대한 발현 유도성에 가장 주요한 역할을 하는 부위로 $\mathrm{ABRE}$ (ABA-responsive element, PyACGTGG/TC)가 보고되었다 $[21,48,53]$. 많은 경우 이러한 $\mathrm{ABRE}$ 는 한 유전자의 프로모터 내에서 다수로 발견되거나, 혹은 다른 cis-acting element (CE, coupling element)와 조합을 이루어 발견된다[55]. 2000년대 초에 두 그룹에 의해 $\mathrm{ABRE}$ 에 의해 결합되는 일련의 bZIP (basic leucine zipper) 전사조절인자 단백질이 yeast one hybrid 테크닉을 통해 보고되었으며 이들은 AREB (ABRE-binding protein) 혹은 $\mathrm{ABF}$ (ABRE binding factors)로 명명되었다 $[9,79]$. 실제 애기장대의 경우 9종류의 해당 유전자족 단백질 이 존재하는 것으로 알려져 있는데, 이들은 다시 상동성에 의 거하여 $\mathrm{AREB} / \mathrm{ABFs}$ 및 $\mathrm{ABI}$ /AtDPBFs (ABA-INSENSITIVE 5/ Arabidopsis Dc3 promoter-binding factors)인 두개의 하위 그룹으로 나누어 질 수 있다[19]. 다수의 연구 보고에 의하면, $\mathrm{AREB} / \mathrm{ABFs}$ 그룹의 주요 전사 조절인자들(AREB1/ABF2, $\mathrm{AREB} 2 / \mathrm{ABF} 4, \mathrm{ABF} 1, \mathrm{ABF} 3)$ 은 가뭄 스트레스시 영양조직 (vegetative tissue)에서 주로 발현되어 앱시스산에 의해 매개 되는 가뭄, 고염(high salt) 스트레스시 그 역할을 수행하는 것 으로 생각되어지는데, 실제로 이러한 기능은 세 종류 단백질 간의 핵에서 형성되는 동형 이량체(homodimer) 혹은 이형 이 량체(heterodimer)에 기인한다. areblareb2abf3 3중 돌연변이체 의 경우, 단일 돌연변이체 및 2 중 돌연변이체에 비해 강화된 
앱시스산에 대한 비감수성과 가뭄저항성 감소 형질을 보이는 데, 이는 상기 3 종류의 단백질이 상호 협동 과정을 통하여 앱 시스산 신호 전달 과정에 양성적으로 기여하고 있음을 나타낸 다 $[17,28,30,79,88]$. 반면, $\mathrm{ABI} 5 / \mathrm{AtDPBFs}$ 그룹의 전사 조절 인자들(ABI5/AtDPBF1, AtDPBF2, AREB3/AtDPBF3, EEL/ $A t D P B F 4)$ 은 씨의 발생, 발아 과정에서 중요한 역할을 하는 것으로 알려져 있는데, 특히 이 중에서도 ABI5는 앱시스산에 의해 매개되는 씨의 발아 지연 및 발아 직후 성장 억제 과정에 서 주요 조절자로 작용한다[12, 14, 30,38, 44].

각 bZIP 단백질들의 활성을 조절하는 번역 후 변형 과정으 로 인산화과정이 관련되어 있음이 다수의 보고를 통해 알려져 왔다(Fig. 1, Fig. 2). 이들의 인산화 및 활성화에 앞서 기술한 SnRK2 인산화 효소가 연관되어 있으며, 실제로 앱시스산 의 존적인 bZIP 단백질내에 존재하는 다수의 RXXS/T 지역의 인 산화가 SnRK2 인산화 효소에 의해 이루어지는 것으로 보인다 [16]. 또한 상기 클래스 III에 해당하는 3종류의 SnRK2가 식물 세포의 핵 내에서 bZIP 단백질들과 함께 존재하는 것으로 보 아, 이러한 인산화 과정은 핵 내에서 실행되는 것으로 여겨진 다[88]. SnRK2.2, SnRK2.6, SnRK2.3를 이용한 이중, 삼중 돌연 변이체를 사용해 연구한 결과, SRK2D/SnRK2.2, SRK2E/ SnRK2.6/OST1, SRK2I/SnRK2.3들이 ABF1, AREB1/ABF2,
$\mathrm{ABI} 5, \mathrm{AREB} 3 / \mathrm{AtDPBF} 3$ 등과 직접적으로 결합하여, 해당 bZIP 단백질의 인산화와 활성, 그리고 앱시스산에 대한 감수 성 등에 직접적으로 영향을 미침이 확인되었다 $[16,56]$. 또한 해당 3중 돌연변이체를 대상으로 수행한 마이크로어레이 (microarray) 분석 결과, 감소되는 유전자들의 목록은 $A R E B 1 /$ $A B F 2, A R E B 2 / A B F 4, A B F 3$ 의 3종류 유전자가 결여된 3중 돌 연변이체에서 감소하는 유전자의 목록과 상당부분 일치하였 다[18]. 이러한 결과들은 클래스 III의 SnRK2 인산화 효소가 앱시스산 신호 전달과정에서 bZIP 단백질의 기능 수행을 위해 중요한 역할을 수행하고 있음을 검증해주고 있다. 흥미롭게도 3 중 $\mathrm{SnRK} 2$ 돌연변이체내에서 특이적으로 $P D F$ 를 포함한 9종 류의 자스몬산(Jasmonic acid) 반응 유전자와 $A P 3, S E P 2$ 를 포 함한 5 종류의 꽃발생 관련 유전자의 발현량 중가가 관찰되는 데 이는 앱시스산 신호 과정이 다른 호르몬 신호 과정 및 세포 내 발생 과정과 복잡하게 연계되어 상호 영향을 끼치고 있음 을 암시한다. 또한 상기 돌연변이체에서는 bZIP 단백질의 인 산화 결여뿐만 아니라, $A R E B 1 / A B F 2, A B F 3$ 의 mRNA 발현 또한 억제됨이 관찰되는데 이는 해당 인산화 효소가 bZIP 단 백질의 번역 후 조절 뿐 아니라 전사 수준에서의 조절에도 관여할 수 있음을 보여준다[18]. 최근의 보고에서, Sirichandra (2010) 등은 SnRK2.6이 ABF3 단백질의 451번째 트레오닌

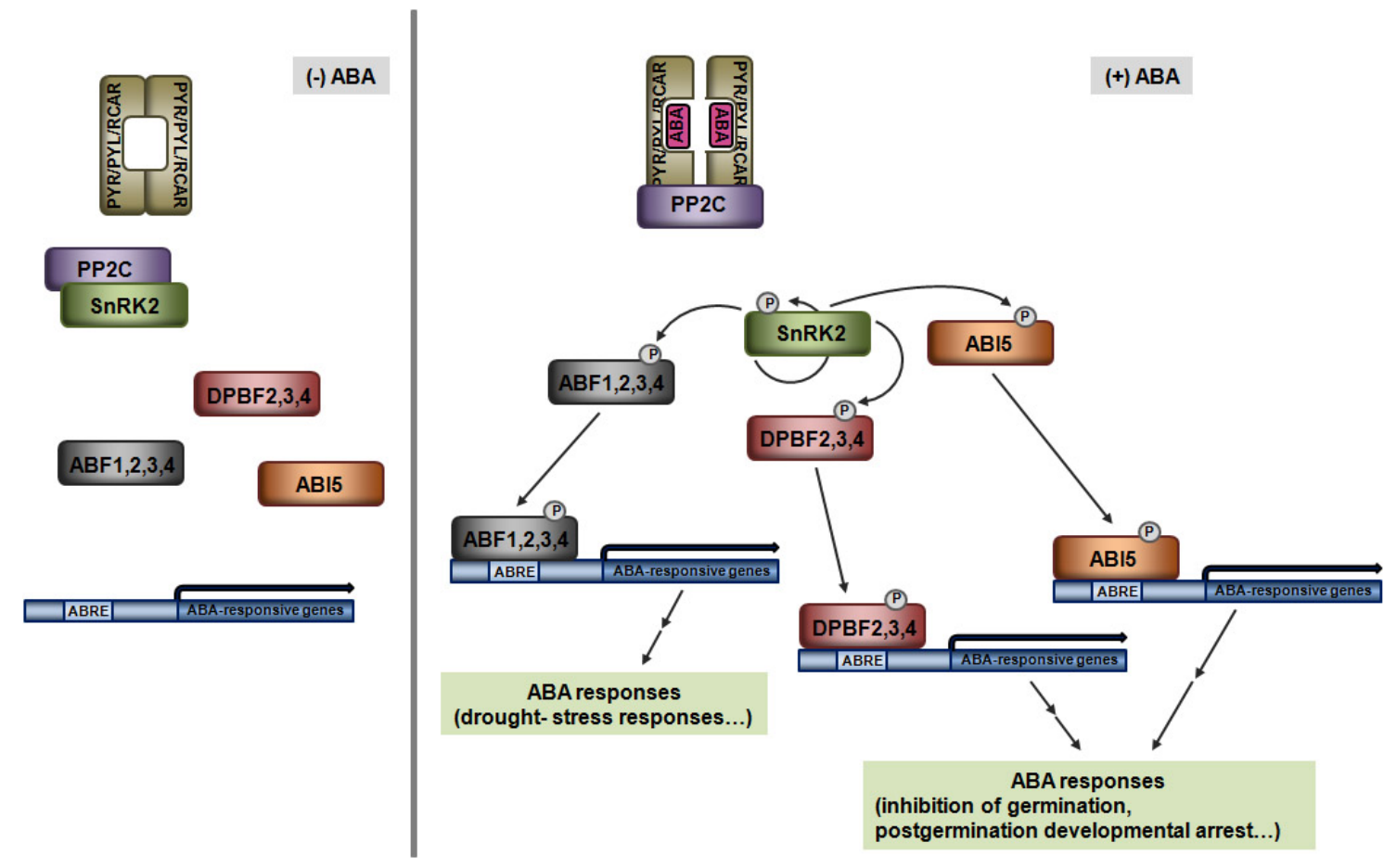

Fig. 1. Proposed model of the ABA-PYR/PYL/RCAR-PP2C-SnRK2-bZIP core signaling pathway. The binding of ABA onto ABA receptor (PYR/PYL/RCAR) triggers the association of ABA-ABA receptor with $\mathrm{PP2C}$ and the dissociation between PP2C and SnRK2. SnRK2 proteins dissociated from PP2C are activated by autophosphorylation and phosphorylate various bZIP proteins such as ABI5, $\mathrm{ABF} 1 / 2 / 3 / 4$ and $\mathrm{DPBF} / 3 / 4$. The activated bZIPs bind to cisacting element for ABA-responsiveness, $\mathrm{ABRE}$, and are involved in the regulation of various ABA-responsive genes. Finally, up-regulated ABA-responsive genes are responsible for diverse $\mathrm{ABA}$ responses in plant cells. 


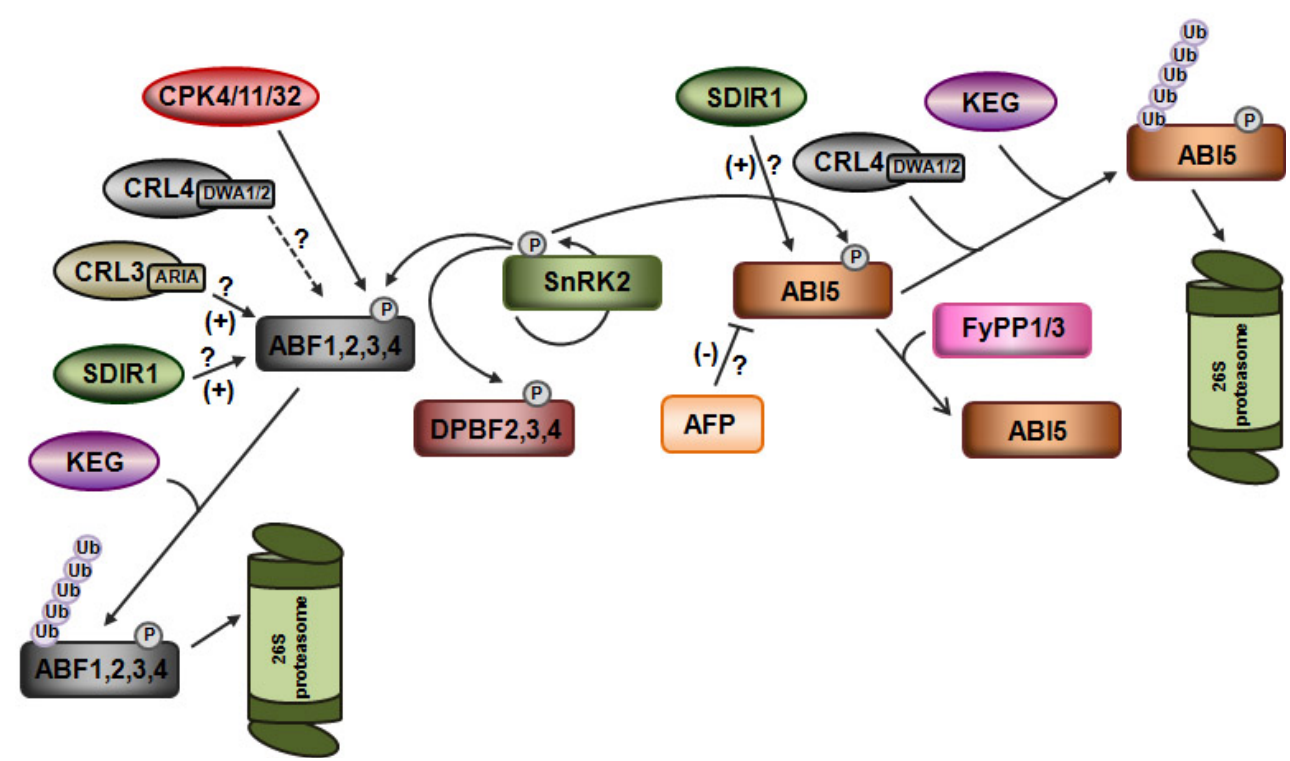

Fig. 2. Post-translational modifications that affect the activity of various signaling components in ABA signal transduction pathway. Several E3 ligases such as KEG, CRL4 ${ }^{\text {DWA1/2 }}, \mathrm{CRL}^{\mathrm{ARIA}}$ and SDIR1 modulate the stability/activity of various bZIP proteins. Besides SnRK2, additional kinases such as CPK4/11/32 also positively regulate several ABFs via phsphorylation. FyPP1/3 and AFPs act as the signaling components to inhibit ABI5 activity via dephosphorylation and by the unknown mechanism, respectively. $(+)$ and $(-)$ indicate positive and negative regulation, respectively. Dotted lines indicate the possible involvement of CRL4 ${ }^{\text {DWA1/2 }}$ in the regulation of ABF1/2/3/4 suggested by Lee et al. [38], since dwa1dwa2 exhibited a drought-tolerant phenotype. Questionmarks indicate that the detail action mechanism has not been identified. Ub: ubiquitin. P: phosphate.

(T451) 인산화를 통해, 인산화된 단백질과 결합하는 조절 단백 질 중 하나인 14-3-3 단백질의 결합 지역을 생성하는데 역할을 함을 보고하였다. $\mathrm{T} 451$ 이 $\mathrm{ABF} 3$ 의 인산화를 통한 활성화 및 단백질 안정성에 중요한 역할을 함에 의거하여 볼 때, 14-3-3 단백질이 $\mathrm{ABF}$ 를 포함한 bZIP 전사 조절 인자의 활성/안정성 을 증가시키는데 기능을 할 수 있음이 예상된다[75].

한편, SnRK2 인산화 효소에 의해 야기되는 bZIP 단백질의 활성화 신호는 어떻게 중지되는가? 이에 대한 해답은 최근에 Wang 그룹에서 발표한 두 종류의 탈인산화 단백질인 FyPP1 (Phytochrome-associated serine/threonine protein phosphatase 1)과 $\mathrm{FyPP3}$ 로부터 찾을 수 있다. $F y P P 1, F y P P 3$ 는 세린/ 트레오닌 탈인산화 효소(serine/threonine protein phosphatase)의 활성 소단위체를 발현시키는 유전자로서, 해당 유전자 가 결여된 돌연변이체의 경우 증가된 앱시스산 감수성, 앱시 스산에 의해 매개되는 씨의 발아 및 유묘 생장 억제 형질을 보인다. 또한, 이들은 $\mathrm{ABI} 5$ 와 직접적인 결합을 통해 $\mathrm{ABI} 5$ 를 탈인산화시키는데, 이러한 결과들은 두 단백질이 $\mathrm{ABI}$ 의 불활 성화를 통해 관련 앱시스산 반응의 음성 조절자로서 역할을 수행함을 제시한다[11].

상기 다수의 결과들은 bZIP 단백질의 활성 조절에 인산화/ 탈인산화 사이클(cycle)이 관여하고 있음을 보여주는데, SnRK2 인산화 효소 이외에도 일련의 칼슘 의존적 인산화 효 소(calcium-dependent protein kinases, CPKs)가 해당 bZIP
단백질의 활성에 영향을 줄 수 있음이 보고되었다. CPK4와 $\mathrm{CPK} 11$ 은 앱시스산 존재 시 $\mathrm{ABF1}$ 및 $\mathrm{AREB} 2 / \mathrm{ABF}$ 를 인산화 시키며, $c p k 4 p k 11$ 이중 돌연변이체가 $\mathrm{ABA}$ 에 대한 다면적인 (pleiotropic) 비감수성을 유발함을 통해 해당 두 단백질이 앱 시스산 신호 전달 과정의 양성 조절자로서 작용을 함을 알 수 있다[93]. 또한, $\mathrm{CPK} 32$ 는 $\mathrm{AREB} 2 / \mathrm{ABF} 4$ 과 직접적으로 결합 을 하며 해당 유전자의 과다발현체가 앱시스산에 대해 증가된 감수성(hypersensitivity)를 보임에 의거할 때, 역시 해당 신호 전달 과정의 양성 조절자로서 기능을 함을 알 수 있다[10]. 최 근의 연구는 놀랍게도 탈인산화 효소 $2 \mathrm{C}$ 단백질들이 일련의 bZIP 단백질 및 CPK11과 직접적으로 결합하여 탈인산화를 통해 해당 전사조절인자들을 비활성화시킬수 있음을 제시하 고 있는데, 이는 탈인산화 효소 2C-SnRK2 인산화 효소(및 FyPP1/3)-bZIP 전사조절인자로 이루어지는 주요 인산화/탈 인산화 과정을 우회하는 별도의 인산화/탈인산화 과정이 존 재함을 보여준다[3, 46].

\section{bZIP (basic leucine zipper) 전사조절인자 안정성/기능 에 관여하는 유비퀴틴화}

앞서 기술한 내용을 통해 앱시스산 신호전달에 주요기능을 수행하는 bZIP (basic leucine zipper) 전사조절인자들의 활성 화에 인산화가 필요함을 알 수 있다. 이외에도, 최근 들어 해당 단백질의 안정성 조절이 앱시스산 신호전달에 주요한 영향을 
미침을 보여주는 일련의 연구가 보고되고 있다(Fig. 2). 이러한 단백질 안정성 조절은 유비퀴틴화를 통해 매개되어지며, 주로 $\mathrm{ABI} 5$ 를 중심으로 연구되어져 왔다. 먼저 ABI5 결합 단백질을 찾기 위한 효모이중잡종 분석법을 통해 AFP (ABI5 binding protein)가 분리되었다[45]. AFP1, $\mathrm{AFP} 2$ 의 돌연변이체 분석을 통해 해당 유전자는 앱시스산 신호의 음성 조절자로 작용하고 있음을 알 수 있다. $a f p$ 돌연변이의 앱시스산에 대한 과다 민감 성(hypersensitivity)이 $\mathrm{ABI}$ 의 과다 축적에 기인하며, $\mathrm{ABI} 5$ 가 유비퀴틴화 의존적 경로(ubiquitination-dependent pathway) 에 의해 분해 가능한점, $\mathrm{AFP}$ 와 $\mathrm{ABI}$ 가 핵내에 함께 위치하는 결과 등을 통해 $\mathrm{AFP}$ 는 $\mathrm{ABI} 5$ 단백질의 유비퀴틴화 의존적 기 작을 통한 분해에 관여하는 것으로 보인다. 뿐만 아니라 총 4 개 의 애기장대 $\mathrm{AFP}$ 단백질들이 다양한 $\mathrm{AREB} / \mathrm{ABF}$ 및 $\mathrm{AtDPBF}$ 그룹 단백질들과 다양한 조합을 통해 결합함을 볼 때 $\mathrm{AFP}$ 들 이 다수 bZIP 단백질의 기능에 영향을 미칠 수 있음이 예상된 다[20]. 그럼에도 불구하고 $\mathrm{AFP}$ 단백질들이 기존의 단백질 분 해에 관여하는 E3 유비퀴틴 연결효소(E3 ubiquitin ligase)들 이 보유한 어떠한 특징적인 도메인을 소유하고 있지 않다는 점에서 이들의 상세 분해 기작은 아직 명확히 밝혀지지 않은 상태이다. $\mathrm{ABI} 5$ 의 단백질 안정성을 직접 조절하는 세 종류의 E3 유비퀴틴 연결효소로 KEG (KEEP ON GOING)과 DWA1 (DWD hypersensitive to ABA 1), DWA2가 보고되었다[38, 77]. KEG는 RING (Really Interesting New Gene) 도메인을 보유한 단일체 E3 연결효소로서(single subunit E3 ligase), 앱 시스산 부재시 $\mathrm{ABI} 5$ 와 직접적으로 결합한 후 폴리유비퀴틴화 를 통해 $\mathrm{ABI}$ 를 분해함으로써 핵내에 존재하는 $\mathrm{ABI} 5$ 의 단백 질 축적량을 감소시키며, 앱시스산의 존재시에는 자체 유비퀴 틴화(self-ubiquitination)을 통해 스스로 분해됨으로써 ABI5 의 축적을 야기한다[42, 43]. 최근의 연구 결과를 통해 $\mathrm{KEG}$ 는 $\mathrm{ABF1}$ 및 $\mathrm{ABF3}$ 의 분해에도 직접 참여함을 알 수 있다[8]. DWA1, DWA2는 컬린(cullin) 단백질을 중심으로 복합체를 형성하는 복합체 E3 연결효소(multi-subunit E3 ligase 혹은 cullin-RING E3 ligase, CRL)의 기질 수용체로 보고되었다. 이 들은 동질이량체(homodimer) 혹은 이질이량체(heterodimer) 로서 cullin4-RING E3 연결효소 복합체(CRL4 complex)와 결 합 후, $\mathrm{ABI}$ 와의 직접적인 결합을 통해 해당 단백질을 분해하 는 음성 조절자로서 알려져 있다[37, 38, 91]. SDIR1 (SALTAND DROUGHT-INDUCED RING FINGER 1)의 경우 RING 도메인을 보유한 단일체 E3 연결효소로서 과다발현시 앱시스 산에 의한 과다 감수성 형질을 발아 지연 및 기공 닫힘 증가, 가뭄 저항성 증가 등을 통해 보여주고 있는데, 이를 통해 상기 E3 유비퀴틴 연결효소들과는 달리 앱시스산 신호 전달의 양성 조절자(positive regulator)로서 작용하는 것으로 보인다. $\mathrm{SDIR} 1$ 은 $\mathrm{ABI} 5, \mathrm{ABF} 3, \mathrm{AREB} 2 / \mathrm{ABF} 4$ 의 상위에서 작용하는데, 아마도 해당 bZIP 단백질의 음성 조절자 분해에 관여할 것으 로 예상된다[92]. AREB1/ABF2와 결합하는 단백질로서 동정
된 ARIA (ARM REPEAT PROTEIN INTERACTING WITH $\mathrm{ABF}$ )는 카르복시 말단(C-terminus) 부위에 CRL3 복합체의 기질 수용체에서 공통적으로 발견되는 $\mathrm{BTB} / \mathrm{POZ}$ (broad complex, tramtrak, and bric-a-brac/poxvirus and zinc finger) 도메인(domain)을 보유하고 있다. Cullin3-RING E3 연결 효소 복합체(CRL3 complex)가 흔히 폴리유비퀴린화(polyubiquitination)을 통해 단백질의 안정성을 감소시키는 기능을 수행함에도 불구하고 $A R I A$ 의 과다발현체가 앱시스산의 과다 감수성을 유발함을 볼 때, ARIA는 AREB1/ABF2의 활성을 양성적으로 조절하고 있음을 알 수 있는데, 이는 ARIA가 보편 적으로 기능하는 폴리유비퀴린화 과정을 통해 ARIA-AREB1/ $\mathrm{ABF} 2$ 와 결합하는 제 3 의 단백질의 안정화에 영향을 미치거나, 혹은 모노유비퀴틴화(monoubiquitination)을 통한 ARIA 단 백질 안정성의 양성적 조절에 관여할 가능성을 암시한다[31].

앞서 기술한 바와 같이, $\mathrm{ABI} / \mathrm{AtDPBFs}$ 그룹과 AREB1/ $\mathrm{ABF} 2, \mathrm{AREB} 2 / \mathrm{ABF} 4, \mathrm{ABF} 1, \mathrm{ABF} 3$ 그룹으로 분류되는 bZIP 단백질들은 구조적 유사성과 앱시스산 신호 전달 과정에서의 중복되는 기능을 보유하고 있는데, 이는 이들의 활성 및 단백 질 안정성 조절이 많은 경우 유사한 방식을 통해 조절받을 가능성이 높음을 의미한다. 그럼에도 불구하고, 현재까지 $\mathrm{ABI} 5$ 를 제외하고 $\mathrm{bZIP}$ 의 유비퀴틴화에 의한 음성적 조절에 대한 보고는 활발히 이루어지지 않고 있는 실정이다. 유비퀴 틴화 활성을 보이는 앱시스산 신호 조절 단백질의 선별을 위 해 가장 효과적인 방법은 특정 $\mathrm{E} 3$ 유비퀴틴 연결효소의 기능 소실로부터 앱시스산 감수성의 변이를 유발하는 기능 소실 돌연변이체를 분리하는 것이다. 문제는 애기장대에 존재하는 E3 유비퀴틴 연결효소가 약 1,400 여 개에 이르기 때문에 이들 의 돌연변이체를 대상으로 앱시스산 감수성을 추적하는 것은 물리적 한계가 따른다는 것인데, 한가지 제안될 수 있는 방법 은 앱시스산에 의해 전사량이 증가하는 $\mathrm{E} 3$ 유비퀴틴 연결효소 유전자를 추적 후, 이들을 대상으로 감수성을 조사하는 것이 다. 일례로, 애기장대 단일체 E3 연결효소 유전자 중 470 개의 RING E3 연결효소 유전자를 대상으로 앱시스산 반응성을 조 사했을 때, 이 중 13 개의 유전자가 앱시스산에 의해 5 배 이상 의 전사량 증가를 보임을 알 수 있다[29, 76](Table 1). 이러한 전략은 앱시스산 신호전달 과정에서 유비퀴틴화에 관여하는 잠재적인 후보자의 범위를 좁히고, 이를 선별하는데 있어 효 율적인 방법 중 하나가 될 수 있으며, bZIP 전사 조절 인자를 포함한 다른 앱시스산 신호 전달 단백질의 안정성 조절 기작 규명과 연계될 수 있다.

\section{$\mathrm{ABI}, \mathrm{AB} \mid 4$, AtMYC2, AtMYB2}

위에서 언급한 bZIP (basic leucine zipper) 전사조절인자 이외에 앱시스산 신호전달에 중요한 기능을 하는 전사조절인 자들이 보고되어 왔다. ABI3 (ABA-INSENSITIVE 3)는 4개의 도메인(A1, B1, B2, B3)을 보유한 단백질인데 이중, B1, B2 도메 
Table 1. Gene list of RING-type ubiquitin ligases that are induced by ABA. From total 470 genes, the genes are increased by more than five-times under ABA treatment have been selected, based on AtGenExpress Visualization Tool (AVT) [29, 76]

\begin{tabular}{|c|c|c|}
\hline AGI & $\begin{array}{l}\text { Induction } \\
\text { fold }\end{array}$ & Induced condition \\
\hline At1g04360 & 7.8 & seedling, $3 \mathrm{hr}, 10 \mu \mathrm{M} \mathrm{ABA}$ \\
\hline At1g30860 & 129.4 & seed, $24 \mathrm{hr}, 30 \mu \mathrm{M}$ ABA \\
\hline At1g32740 & 7.6 & seedling, $3 \mathrm{hr}, 10 \mu \mathrm{M} \mathrm{ABA}$ \\
\hline At2g22680 & 9.9 & seedling, $3 \mathrm{hr}, 10 \mu \mathrm{M} \mathrm{ABA}$ \\
\hline At2g37150 & 11.8 & seedling, $3 \mathrm{hr}, 10 \mu \mathrm{M} \mathrm{ABA}$ \\
\hline At3g09770 & 6.7 & seedling, $3 \mathrm{hr}, 10 \mu \mathrm{M} \mathrm{ABA}$ \\
\hline At3g10910 & 13.9 & seedling, $3 \mathrm{hr}, 10 \mu \mathrm{M} \mathrm{ABA}$ \\
\hline At4g23450 & 159.7 & seedling, $3 \mathrm{hr}, 10 \mu \mathrm{M} \mathrm{ABA}$ \\
\hline At4g35070 & 7.2 & seed, $24 \mathrm{hr}, 30 \mu \mathrm{M} \mathrm{ABA}$ \\
\hline At4g35480 & 15.1 & seedling, $3 \mathrm{hr}, 10 \mu \mathrm{M} \mathrm{ABA}$ \\
\hline At5g 01520 & 5.5 & seedling, $3 \mathrm{hr}, 10 \mu \mathrm{M} \mathrm{ABA}$ \\
\hline At5g42200 & 17.2 & seedling, $3 \mathrm{hr}, 10 \mu \mathrm{M} \mathrm{ABA}$ \\
\hline At5g55970 & 32.5 & seedling, $3 \mathrm{hr}, 10 \mu \mathrm{M} \mathrm{ABA}$ \\
\hline
\end{tabular}

인이 핵으로의 이동 및 다른 단백질(ABI5를 포함한 일련의 bZIP 전사조절인자)과의 상호작용에 중요한 역할을 하는 반 면, B3 도메인은 RY 모티브(CATGCA)라 불리는 cisacting element와의 결합을 통해 특정 유전자의 활성 증가에 중요한 역할을 하는 부위로 알려져 있다[36, 51, 54, 78]. ABI3에 의해 조절되는 다수의 유전자들의 프로모터내에 RY 모티브외에도 G-box (혹은 ABRE)를 포함하는 것으로 보아 해당 유전자의 발현을 위해 $\mathrm{ABI}$ 와 상기 $\mathrm{bZIP}$ 단백질들간의 상호 작용이 중 요함을 알 수 있다. 돌연변이체 연구를 근거하여 볼 때, $\mathrm{ABI}$ 는 식물의 씨 발달 단계, 씨 휴면, 발아 및 앱시스산 반응성에 관여하며 중요한 역할을 하며, 배의 발달 단계 관련 유전자인 LEA (late embryogenesis abundant)의 발현 조절에 중요한 역할 을 하는 것으로 보인다[65]. ABI5와 유사하게, $\mathrm{ABI} 3$ 역시 의존 적인 $26 \mathrm{~S}$ 프로테아좀 의존적 경로(26S proteasome-dependent pathway)에 의해 단백질의 음성적 조절을 받는다. AIP2 (ABI3-interacting protein 2)는 RING 타입의 단일체 E3 연결 효소로서 $\mathrm{ABI}$ 의 $\mathrm{A} 1, \mathrm{~B} 1$ 도메인을 유비퀴틴화시키는데, aip2-1 돌연변이체의 앱시스산 과다감수성 및 $\mathrm{ABI}$ 단백질의 과다축 적 등은 $\mathrm{AIP} 2$ 가 $\mathrm{ABI}$ 단백질 분해에 직접적으로 기능함을 보 여준다[90].

ABI4는 식물에서 다유전자족(multigene family)로 존재하 는 AP2 (APETALA2) 유전자족(Drought Response Element Binding factors, DREBs 와 Ethylene Response Element Binding Proteins, EREBPs 그륩을 포함)에 속하는 전사조절 인자로 알려져 있다[15]. 해당 유전자족 대부분의 전사조절인 자들이 DRE, GCC box로 알려진 cis-acting element에 결합하 는 것과 달리, $\mathrm{ABI} 4$ 는 이와 다른 별도의 프로모터 지역인 coupling element 1 (CE1, CACCG), S-box (CACYKSCA)에 결합
하는 것으로 보고되어 왔다 $[4,61,63,68]$. 돌연변이를 이용한 생리학적 연구를 통해 $\mathrm{ABI} 3, \mathrm{ABI} 4, \mathrm{ABI}$ 전사 조절 인자들은 앱시스산 감수성, 발아 및 씨 발달 과정에 공통적으로 중요한 역할을 하는 것으로 알려져 왔으며, 앱시스산에 의한 유전자 조절에 적어도 부분적으로는 상기 전사조절 인자들의 조합을 통한 조절 복합체의 존재가 관여할 것이라 예상되어지고 있다 $[14,15,57,65]$. 최근의 연구는 ABI4에 반응하는 유전자들 중 다수가 상기 알려진 CE1, S-box를 갖는 대신 ABRE를 보유하 고 있으며 실제로 $\mathrm{ABI} 4$ 와 일부 $\mathrm{ABRE}$ 보유 유전자간의 결합이 가능함을 보여주는데, 이는 $\mathrm{AB} 4$ 의 프로모터로의 결합능이 유 연성을 보임을 암시한다[67]. 일부 ABI4는 전사 조절시 ABI5 및 bZIP과 함께 해당 유전자의 발현을 협동적으로 조절하는 것으로 보이는데, 실례로 스트레스 조건하에서 트리아실글리 세롤(triacylglycerol) 합성의 주 효소인 DGAT1 (Diacylglycerd acyltransferase 1) 유전자의 발현을 ABI4, ABI5가 함께 상승적 으로(synergistic) 조절한다 [32, 67].

비생물적(abiotic) 스트레스 관련 유전자를 조절하는 대표 적인 전사조절인자로 $\mathrm{MYC} / \mathrm{MYB}$ 그룹이 존재한다. 이중 애기 장대의 AtMYC2, AtMYB2는 앱시스산 반응성에 관여하는 전 사조절인자로 보고되었으며, 각각 MYCRS 및 MYBRS (MYC혹은 MYB-recognition sequence)를 앱시스산 반응 유전자의 프로모터내 인식부위로 보유하고 있다[2]. 두 유전자의 과다발 현 형질전환체는 앱시스산에 대한 과다감수성 형질을 보이며, 주요 앱시스산 반응 유전자 중 하나인 $R D 22$ 유전자의 발현을 증가시킴을 통해, 해당 단백질들이 앱시스산 반응성의 양성조 절자로 작용함을 알 수 있다[1]. 앞서 언급한 DWA1, DWA2의 돌연변이체는 앱시스산 존재 하에서 야생종과 비교시, $A t M Y C 2$ 전사량의 차이는 보이지 않았으나 AtMYC2의 단백질의 과다 축적을 유발했는데, 이는 DWA1, DWA2가 AtMYC2 단백질 의 음성적 조절에 관여될 수 있음을 암시한다. DWA1, DWA2 와 AtMYC2 간의 직접적인 결합이 이루어지지 않는 것으로 보아, 이러한 조절은 다른 단백질의 매개하에 이루어질 가능 성이 높다[38].

\section{결 론}

식물은 동물과 달리 외부 환경으로부터의 스트레스를 피해 이동할 수 있는 능력을 보유하고 있지 않으므로, 환경적 스트 레스에 대해 효율적인 저항성을 나타내기 위한 정교하고 체계 적인 생체 내 조절 시스템을 구축하여 왔다. 다양한 환경적 스트레스 중 식물이 가장 빈번하게 경험하게 되는 스트레스는 물부족으로 인해 유래되는 가뭄 스트레스로서, 실제로 지구상 다수의 국가가 이러한 스트레스에 의해 작물 생산량의 심각한 손실을 겪고 있다. 이에 가뭄 저항성과 관계된 신호전달 기작 을 명확히 이해하고자 하는 연구가 활발히 진행되고 있으며, 상기 신호 전달에 관여하는 신호전달 물질의 분리 및 기능 규명에 많은 에너지가 투입되고 있는 실정이다. 가뭄 스트레 
스 신호 전달 물질의 분리를 위해서 가장 빈번하게 사용되는 연구 기법은 기능 소실 혹은 기능 획득 돌연변이의 형질 스크 리닝을 통한 관련 유전자의 선별이며, 이러한 과정을 통한 가 뭄 저항성 돌연변이의 신속하고 효율적인 선별은 가뭄 저항성 과 관계된 앱시스산 감수성 변이 돌연변이체의 추적을 통해 보다 용이해질 수 있다. 앱시스산은 가뭄저항성 뿐 아니라 초 기 씨앗의 발달(씨앗의 성숙, 발아, 휴면 등) 과정에서도 중요 한 역할을 담당하므로 산업적 응용 가치가 높은 호르몬이라 할 수 있으며, 이에 앱시스산 신호전달 기작의 명확한 규명은 필수적이라 할 수 있다. 다른 호르몬과 달리 앱시스산의 경우 하위단계 신호전달물질의 및 전달 체계는 활발히 연구된 반 면, 수용체의 발견은 오랜 기간동안 이루어지지 않아왔는데, 2009년부터 분리되기 시작한 주요 앱시스산 수용체의 발견은 앱시스산의 주신호전달과정을 비로소 정립하는데 크게 공헌 하였다. 그럼에도 불구하고 앱시스산 수용체-탈인산화 효소 2C-SnRK2 인산화 효소-bZIP 전사조절인자로 이루어지는 주 요 신호전달과정에서 풀어야 할 숙제는 여전히 많이 남아있 다. 상기 기술한 바와 같이, $\mathrm{bZIP}$ 전사조절인자 중 $\mathrm{ABI} 5$ 를 제 외하고 나머지 단백질들의 유비퀴틴 의존적인 안정성 조절에 대한 보고는 아직도 미흡한 실정이며, ABI5/AtDPBFs 그룹이 주로 담당하는 씨의 발생, 발아 과정과 $\mathrm{AREB} / \mathrm{ABFs}$ 그룹이 주로 담당하는 스트레스 저항성이 어떠한 세부 기작에 의해 구별되어 조절되는지에 대한 연구도 아직 체계적으로 정립되 어 있지 않다. 게다가 bZIP 전사조절인자의 하위 단계에서 전 사량을 조절받는 다수의 앱시스산 반응 유전자들의 상세 기능 에 대한 연구 역시 부족한 실정이다. 다수의 앱시스산 반응 유전자의 프로모터 지역에는 bZIP 전사조절인자가 인지하는 $\mathrm{ABRE}$ 외에도 $\mathrm{CE} 1, \mathrm{CE} 3, \mathrm{DRE}, \mathrm{RY}$ 등의 다양한 cisacting element 부위가 짝지어 존재하는데, 이는 다양한 그룹의 전사 조절 인자간의 상호 작용을 통한 세밀한 조정(fine-tuning)이 앱시스산 반응 유전자의 발현 조절에 있어 요구됨을 암시하므 로 관련 기작의 상세한 규명 역시 필요할 것으로 여겨진다[25, $51,55,73,78]$.

본 총설을 통해 최근까지 업데이트된 앱시스산 신호 전달 기작을 상세히 이해하고자 하였다. 상기 기작의 상세한 이해 를 기반으로 하여, 이를 가뭄 저항성과 관련된 작물 유전자의 선별 및 해당 유전자 발현량 조절을 통한 형질전환체의 제작 (혹은 모델 식물 유전자 선별 후 작물로의 적용을 통한 형질전 환체의 제작)에 적용할 수 있다면, 재배 지역의 확장 및 유용한 약용, 식량, 에너지 작물의 생산량 개선에 크게 도움이 될 것이 다. 이는 국내외 농업 분야의 발전 및 농가의 소득 증대에 긍정 적 효과를 산출할 수 있을 것으로 기대된다.

\section{감사의 글}

이 논문은 부산대학교 자유과제 학술연구비(2년)에 의하여 연구되었음.

\section{References}

1. Abe, H., Urao, T., Ito, T., Seki, M., Shinozaki, K. and Yamaguchi-Shinozaki, K. 2003. Arabidopsis AtMYC2 (bHLH) and AtMYB2 (MYB) function as transcriptional activators in abscisic acid signaling. Plant Cell 15, 63-78.

2. Abe, H., Yamaguchi-Shinozaki, K., Urao, T., Iwasaki, T., Hosokawa, D. and Shinozaki, K. 1997. Role of Arabidopsis MYC and MYB homologs in drought- and abscisic-acidregulated gene expression. Plant Cell 9, 1859-1868.

3. Antoni, R., Gonzalez-Guzman, M., Rodriguez, L., Rodrigues, A., Pizzio, G. A. and Rodriguez, P. L. 2012. Selective inhibition of clade A phosphatases type 2C by PYR/PYL/ RCAR abscisic acid receptors. Plant Physiol 158, 970-980.

4. Bossi, F., Cordoba, E., Dupre, P., Mendoza, M. S., Roman, C. S. and Leon, P. 2009. The Arabidopsis ABA-INSENSITIVE (ABI) 4 factor acts as a central transcription activator of the expression of its own gene, and for the induction of ABI5 and SBE2.2 genes during sugar signaling. Plant J 59, 359-374.

5. Boyer, J. S. 1982. Plant productivity and environment. Science 218, 443-448.

6. Chen, H., Lai, Z., Shi, J., Xiao, Y., Chen, Z. and Xu, X. 2010. Roles of Arabidopsis WRKY18, WRKY40 and WRKY60 transcription factors in plant responses to abscisic acid and abiotic stress. BMC Plant Biol 10, 281.

7. Chen, Y. H., Hu, L., Punta, M., Bruni, R., Hillerich, B., Kloss, B., Rost, B., Love, J., Siegelbaum, S. A. and Hendrickson, W. A. 2010. Homologue structure of the SLAC1 anion channel for closing stomata in leaves. Nature 467, 1074-1080.

8. Chen, Y. T., Liu, H, Stone, S. and Callis, J. 2013. ABA and the ubiquitin E3 ligase KEEP ON GOING affect proteolysis of the Arabidopsis thaliana transcription factors ABF1 and ABF3. Plant J 75, 965-976.

9. Choi, H., Hong, J., Ha, J., Kang, J. and Kim, S. Y. 2000. ABFs, a family of ABA-responsive element binding factors. J Biol Chem 275, 1723-1730.

10. Choi, H. I., Park, H. J., Park, J. H., Kim, S., Im, M. Y., Seo, H. H., Kim, Y. W., Hwang, I. and Kim, S. Y. 2005. Arabidopsis calcium-dependent protein kinase AtCPK32 interacts with $\mathrm{ABF} 4$, a transcriptional regulator of abscisic acid-responsive gene expression, and modulates its activity. Plant Physiol 139, 1750-1761

11. Dai, M., Xue, Q., Mccray, T., Margavage, K., Chen, F., Lee, J. H., Nezames, C. D., Guo, L., Terzaghi, W., Wan, J., Deng, X. W. and Wang, H. 2013. The PP6 phosphatase regulates ABI5 phosphorylation and abscisic acid signaling in Arabidopsis. Plant Cell 25, 517-534.

12. Finkelstein, R., Gampala, S. S., Lynch, T. J., Thomas, T. L. and Rock, C. D. 2005. Redundant and distinct functions of the ABA response loci ABA-INSENSITIVE (ABI) 5 and ABRE-BINDING FACTOR (ABF) 3. Plant Mol Biol 59, 253-267.

13. Finkelstein, R. R., Gampala, S. S. and Rock, C. D. 2002. Abscisic acid signaling in seeds and seedlings. Plant Cell 14, S15-S45.

14. Finkelstein, R. R. and Lynch, T. J. 2000. The Arabidopsis ab- 
scisic acid response gene ABI5 encodes a basic leucine zipper transcription factor. Plant Cell 12, 599-609.

15. Finkelstein, R. R., Wang, M. L., Lynch, T. J., Rao, S. and Goodman, H. M. 1998. The Arabidopsis abscisic acid response locus ABI4 encodes an APETALA 2 domain protein. Plant Cell 10, 1043-1054.

16. Fujii, H., Verslues, P. E. and Zhu, J. K. 2007. Identification of two protein kinases required for abscisic acid regulation of seed germination, root growth, and gene expression in Arabidopsis. Plant Cell 19, 485-494.

17. Fujita, Y., Fujita, M., Satoh, R., Maruyama, K., Parvez, M. M., Seki, M., Hiratsu, K., Ohme-Takagi, M., Shinozaki, K. and Yamaguchi-Shinozaki, K. 2005. AREB1 is a transcription activator of novel ABRE-dependent ABA signaling that enhances drought stress tolerance in Arabidopsis. Plant Cell 17, 3470-3488

18. Fujita, Y., Nakashima, K., Yoshida, T., Katagiri, T., Kidokoro, S., Kanamori, N., Umezawa, T., Fujita, M., Maruyama, K., Ishiyama, K., Kobayashi, M., Nakasone, S., Yamada, K., Ito, T., Shinozaki, K. and Yamaguchi-Shinozaki, K. 2009. Three SnRK2 protein kinases are the main positive regulators of abscisic acid signaling in response to water stress in Arabidopsis. Plant Cell Physiol 50, 2123-2132.

19. Fujita, Y., Yoshida, T. and Yamaguchi-Shinozaki, K. 2013. Pivotal role of the AREB/ABF-SnRK2 pathway in ABREmediated transcription in response to osmotic stress in plants. Physiol Plant 147, 15-27.

20. Garcia, M. E., Lynch, T., Peeters, J., Snowden, C. and Finkelstein, R. 2008. A small plant-specific protein family of $\mathrm{ABI}$ five binding proteins (AFPs) regulates stress response in germinating Arabidopsis seeds and seedlings. Plant Mol Biol 67, 643-658.

21. Gómez-Porras, J. L., Riaño-Pachón, D. M., Dreyer, I., Mayer, J. E. and Mueller-Roeber, B. 2007. Genome-wide analysis of ABA-responsive elements ABRE and CE3 reveals divergent patterns in Arabidopsis and rice. BMC Genomics 8, 260.

22. Gonzalez-Guzman, M., Pizzio, G. A., Antoni, R., VeraSirera, F., Merilo, E., Bassel, G. W., Fernández, M. A., Holdsworth, M. J., Perez-Amador, M. A., Kollist, H. and Rodriguez, P. L. 2012. Arabidopsis PYR/PYL/RCAR receptors play a major role in quantitative regulation of stomatal aperture and transcriptional response to abscisic acid. Plant Cell 24, 2483-2496.

23. Guo, J., Yang, X., Weston, D. J. and Chen, J. G. 2011. Abscisic acid receptors: past, present and future. J Integr Plant Biol $53,469-479$.

24. Himmelbach, A., Yang, Y. and Grill, E. 2003. Relay and control of abscisic acid signaling. Curr Opin Plant Bid 6, 470-479.

25. Hobo, T., Asada, M., Kowyama, Y. and Hattori, T. 1999. ACGT-containing abscisic acid response element (ABRE) and coupling element 3 (CE3) are functionally equivalent. Plant J 19, 679-689.

26. Hubbard, K. E., Nishimura, N., Hitomi, K., Getzoff, E. D. and Schroeder, J. I. 2010. Early abscisic acid signal transduction mechanisms: newly discovered components and newly emerging questions. Genes Dev 24, 1695-1708.
27. Kang, J., Hwang, J. U., Lee, M., Kim, Y. Y., Assmann, S. M., Martinoia, E. and Lee, Y. 2010. PDR-type ABC transporter mediates cellular uptake of the phytohormone abscisic acid. Proc Natl Acad Sci USA 107, 2355-2360.

28. Kang, J. Y., Choi, H. I., Im, M. Y. and Kim, S. Y. 2002. Arabidopsis basic leucine zipper proteins that mediate stress-responsive abscisic acid signaling. Plant Cell 14, 343357.

29. Kilian, J., Whitehead, D., Horak, J., Wanke, D., Weinl, S., Batistic, O., D'Angelo, C., Bornberg-Bauer, E., Kudla, J. and Harter, K. 2007. The AtGenExpress global stress expression data set: protocols, evaluation and model data analysis of UV-B light, drought and cold stress responses. Plant J 50, 347-363.

30. Kim, S. Y., Ma, J., Perret, P., Li, Z. and Thomas, T. L. 2002. Arabidopsis ABI5 subfamily members have distinct DNAbinding and transcriptional activities. Plant Physiol 130, 688-697.

31. Kim, S., Choi, H. I., Ryu, H. J., Park, J. H., Kim, M. D. and Kim, S. Y. 2004. ARIA, an Arabidopsis arm repeat protein interacting with a transcriptional regulator of abscisic acid-responsive gene expression, is a novel abscisic acid signaling component. Plant Physiol 136, 3639-3648.

32. Kong, Y., Chen, S., Yang, Y. and An, C. 2013. ABA-insensitive (ABI) 4 and ABI5 synergistically regulate DGAT1 expression in Arabidopsis seedlings under stress. FEBS Lett 587, 3076-3082

33. Kuhn, J. M., Boisson-Dernier, A., Dizon, M. B., Maktabi, M. H. and Schroeder, J. I. 2006. The protein phosphatase AtPP2CA negatively regulates abscisic acid signal transduction in Arabidopsis, and effects of abh1 on AtPP2CA mRNA. Plant Physiol 140, 127-139.

34. Kuromori, T., Miyaji, T., Yabuuchi, H., Shimizu, H., Sugimoto, E., Kamiya, A., Moriyama, Y. and Shinozaki, K. 2010. ABC transporter AtABCG25 is involved in abscisic acid transport and responses. Proc Natl Acad Sci USA 107, 2361-2366.

35. Kuromori, T., Sugimoto, E. and Shinozaki, K. 2011. Arabidopsis mutants of AtABCG22, an ABC transporter gene, increase water transpiration and drought susceptibility. Plant J 67, 885-894.

36. Lara, P., Oñate-Sánchez, L., Abraham, Z., Ferrándiz, C., Díaz, I., Carbonero, P. and Vicente-Carbajosa, J. 2003. Synergistic activation of seed storage protein gene expression in Arabidopsis by $\mathrm{ABI} 3$ and two bZIPs related to OPAQUE2. J Biol Chem 278, 21003-21011.

37. Lee, J. H., Terzaghi, W., Gusmaroli, G., Charron, J. B., Yoon, H. J., Chen, H., He, Y. J., Xiong, Y. and Deng, X. W. 2008. Characterization of Arabidopsis and rice DWD proteins and their roles as substrate receptors for CUL4-RING E3 ubiquitin ligases. Plant Cell 20, 152-167.

38. Lee, J. H., Yoon, H. J., Terzaghi, W., Martinez, C., Dai, M., Li, J., Byun, M. O. and Deng, X. W. 2010. DWA1 and DWA2, two Arabidopsis DWD protein components of CUL4-based E3 ligases, act together as negative regulators in ABA signal transduction. Plant Cell 22, 1716-1732.

39. Lee, S. C., Lan, W. Z., Buchanan, B. B. and Luan, S. 2009. 
A protein kinase-phosphatase pair interacts with an ion channel to regulate ABA signaling in plant guard cells. Proc Natl Acad Sci USA 106, 21419-21424.

40. Leung, J., Bouvier-Durand, M., Morris, P. C., Guerrier, D., Chefdor, F. and Giraudat, J. 1994. Arabidopsis ABA response gene ABI1: features of a calcium-modulated protein phosphatase. Science 264, 1448-1452.

41. Leung, J., Merlot, S. and Giraudat, J. 1997. The Arabidopsis ABSCISIC ACID-INSENSITIVE2 (ABI2) and ABI1 genes encode homologous protein phosphatases $2 \mathrm{C}$ involved in abscisic acid signal transduction. Plant Cell 9, 759-771.

42. Liu, H. and Stone, S. L. 2010. Abscisic acid increases Arabidopsis ABI5 transcription factor levels by promoting KEG E3 ligase self-ubiquitination and proteasomal degradation. Plant Cell 22, 2630-2641.

43. Liu, H. and Stone, S. L. 2013. Cytoplasmic degradation of the Arabidopsis transcription factor abscisic acid insensitive 5 is mediated by the RING-type E3 ligase KEEP ON GOING. I Biol Chem 288, 20267-20279.

44. Lopez-Molina, L., Mongrand, S. and Chua, N. H. 2001. A postgermination developmental arrest checkpoint is mediated by abscisic acid and requires the ABI5 transcription factor in Arabidopsis. Proc Natl Acad Sci USA 98, 4782-4787.

45. Lopez-Molina, L., Mongrand, S., Kinoshita, N. and Chua, N. H. 2003. AFP is a novel negative regulator of ABA signaling that promotes ABI5 protein degradation. Genes Dev 17, 410-418.

46. Lynch, T., Erickson, B. J. and Finkelstein, R. R. 2012. Direct interactions of $\mathrm{ABA}$-insensitive( $\mathrm{ABI})$-clade protein phosphatase(PP)2Cs with calcium-dependent protein kinases and ABA response element-binding bZIPs may contribute to turning off ABA response. Plant Mol Biol 80, 647-658.

47. Ma, Y., Szostkiewicz, I., Korte, A., Moes, D., Yang, Y., Christmann, A. and Grill, E. 2009. Regulators of PP2C phosphatase activity function as abscisic acid sensors. Science 324, 1064-1068

48. Maruyama, K., Todaka, D., Mizoi, J., Yohisda, T., Kidokoro, S., Matsukura, S., Takasaki, H., Sakurai, T., Yamamoto, Y. Y., Yoshiwara, K., Kojima, M., Sakakibara, H., Shinozaki, K. and Yamaguchi-Shinozaki, K. 2012. Identification of cis-acting promoter elements in cold-dehydration-induced transcriptional pathways in Arabidopsis, rice, and soybean. DNA Res 19, 37-49.

49. McCourt, P. 1999. Genetic analysis of hormone signaling. Annu Rev Plant Physiol Plant Mol Biol 50, 219-243.

50. Meyer, K., Leube, M. P. and Grill, E. 1994. A protein phosphatase 2C involved in ABA signal transduction in Arabidopsis thaliana. Science 264, 1452-1455.

51. Mönke, G., Altschmied, L., Tewes, A., Reidt, W., Mock, H. P., Bäumlein, H. and Conrad, U. 2004. Seed-specific transcription factors ABI3 and FUS3: Molecular interaction with DNA. Planta 219, 158-166.

52. Muller, A. H. and Hansson, M. 2009. The barley magnesium chelatase $150-\mathrm{kD}$ subunit is not an abscisic acid receptor. Plant Physiol 150, 157-166.

53. Mundy, J., Yamaguchi-Shinozaki, K. and Chua, N. H. 1990.
Nuclear proteins bind conserved elements in the abscisic acid-responsive promoter of a rice rab gene. Proc Natl Acad Sci USA 87, 1406-1410.

54. Nakamura, S., Lynch, T. J. and Finkelstein, R. R. 2001. Physical interactions between ABA response loci of Arabidopsis. Plant J 26, 627-635.

55. Nakashima, K., Fujita, Y., Katsura, K., Maruyama, K., Narusaka, Y., Seki, M., Shinozaki, K. and Yamaguchi-Shinozaki, K. 2006. Transcriptional regulation of ABI3- and ABA-responsive genes including RD29B and RD29A in seeds, germinating embryos, and seedlings of Arabidopsis. Plant $\mathrm{Mol}$ Biol 60, 51-68.

56. Nakashima, K., Fujita, Y., Kanamori, N., Katagiri, T., Umezawa, T., Kidokoro, S., Maruyama, K., Yoshida, T., Ishiyama, K., Kobayashi, M., Shinozaki, K. and Yamaguchi-Shinozaki, K. 2009. Three Arabidopsis SnRK2 protein kinases, SRK2D/ SnRK2.2, SRK2E/SnRK2.6/OST1 and SRK2I/SnRK2.3, involved in ABA signaling are essential for the control of seed development and dormancy. Plant Cell Physiol 50, 1345-1363.

57. Nambara, E., Keith, K., McCourt, P. and Naito, S. 1995. A regulatory role for the $\mathrm{ABI} 3$ gene in the establishment of embryo maturation in Arabidopsis. Development 121, 629-686.

58. Nishimura, N., Hitomi, K., Arvai, A. S., Rambo, R. P., Hitomi, C., Cutler, S. R., Schroeder, J. I. and Getzoff, E. D. 2009. Structural mechanism of abscisic acid binding and signaling by dimeric PYR1. Science 326, 1373-1379.

59. Nishimura, N., Sarkeshik, A., Nito, K., Park, S. Y., Wang, A., Carvalho, P. C., Lee, S., Caddell, D. F., Cutler, S. R., Chory, J., Yates, J. R. and Schroeder, J. I. 2010. PYR/ PYL/RCAR family members are major in-vivo ABI1 protein phosphatase 2C-interacting proteins in Arabidopsis. Plant $J$ 61, 290-299.

60. Nishimura, N., Yoshida, T., Kitahata, N., Asami, T., Shinozaki, K. and Hirayama, T. 2007. ABA-Hypersensitive Germination1 encodes a protein phosphatase 2C, an essential component of abscisic acid signaling in Arabidopsis seed. Plant J 50, 935-949.

61. Niu, X., Helentjaris, T. and Bate, N. J. 2002. Maize ABI4 binds coupling element 1 in abscisic acid and sugar response genes. Plant Cell 14, 2565-2575.

62. Okamoto, M., Tanaka, Y., Abrams, S. R., Kamiya, Y., Seki, M. and Nambara, E. 2009. High humidity induces abscisic acid 8 ' -hydroxylase in stomata and vasculature to regulate local and systemic abscisic acid responses in Arabidopsis. Plant Physiol 149, 825-834.

63. Ohme-Takagi, M. and Shinshi, H. 1995. Ethylene-inducible DNA binding proteins that interact with an ethylene-responsive element. Plant Cell 7, 173-182.

64. Pandey, S., Nelson, D. C., Assmann, S. M. 2009. Two novel GPCR-type $G$ proteins are abscisic acid receptors in Arabidopsis. Cell 136, 136-148.

65. Parcy, F., Valon, C., Raynal, M., Gaubiercomella, P., Delseny, M. and Giraudat, J. 1994. Regulation of gene-expression programs during Arabidopsis seed development: Roles of the ABI3 locus and of endogenous abscisic-acid. Plant Cell 6, 1567-1582. 
66. Park, S. Y., Fung, P., Nishimura, N., Jensen, D. R., Fujii, H., Zhao, Y., Lumba, S., Santiago, J., Rodrigues, A., Chow, T. F., Alfred, S. E., Bonetta, D., Finkelstein, R., Provart, N. J., Desveaux, D., Rodriguez, P. L., McCourt, P., Zhu, J. K., Schroeder, J. I., Volkman, B. F. and Cutler, S. R. 2009. Abscisic acid inhibits type $2 \mathrm{C}$ protein phosphatases via the PYR/PYL family of START proteins. Science 324, 1068-1071.

67. Reeves, W. M., Lynch, T. J., Mobin, R. and Finkelstein, R. R. 2011. Direct targets of the transcription factors ABAInsensitive (ABI) 4 and $A B I 5$ reveal synergistic action by ABI4 and several bZIP ABA response factors. Plant Mol Bid $75,347-363$.

68. Sakuma, Y., Liu, Q., Dubouzet, J. G., Abe, H., Shinozaki, K. and Yamaguchi-Shinozaki, K. 2002. DNA-binding specificity of the ERF/AP2 domain of Arabidopsis DREBs, transcription factors involved in dehydration- and cold-inducible gene expression. Biochem Biophys Res Comm 290, 998-1009.

69. Sánchez-Vallet, A., López, G., Ramos, B., Delgado-Cerezo, M., Riviere, M. P., Llorente, F., Fernández, P. V., Miedes, E., Estevez, J. M., Grant, M. and Molina, A. 2012. Disruption of abscisic acid signaling constitutively activates Arabidopsis resistance to the necrotrophic fungus Plectosphaerella cucumerina. Plant Physiol 160, 2109-2124.

70. Santiago, J., Dupeux, F., Round, A., Antoni, R., Park, S. Y., Jamin, M., Cutler, S. R., Rodriguez, P. L. and Márquez, J. A. 2009. The abscisic acid receptor PYR1 in complex with abscisic acid. Nature 462, 665-668.

71. Sato, A., Sato, Y., Fukao, Y., Fujiwara, M., Umezawa, T., Shinozaki, K., Hibi, T., Taniguchi, M., Miyake, H., Goto, D. B. and Uozumi, N. 2009. Threonine at position 306 of the KAT1 potassium channel is essential for channel activity and is a target site for ABA-activated SnRK2/OST1/ SnRK2.6 protein kinase. Biochem $J$ 424, 439-448.

72. Shang, Y., Yan, L., Liu, Z., Cao, Z., Mei, C., Xin, Q., Wu, F. Q., Wang, X. F., Du, S. Y., Jiang, T., Zhang, X. F., Zhao, R., Sun, H. L., Liu, R., Yu, Y. T. and Zhang, D. P. 2010. The Mg-chelatase $\mathrm{H}$ subunit of Arabidopsis antagonizes a group of WRKY transcription repressors to relieve ABA-responsive genes of inhibition. Plant Cell 22, 1909-1935.

73. Shen, Q. and Ho, T. H. 1995. Functional dissection of an abscisic acid (ABA)-inducible gene reveals two independent ABA-responsive complexes each containing a G-box and a novel cis-acting element. Plant Cell 7, 295-307.

74. Shen, Y. Y., Wang, X. F., Wu, F. Q., Du, S. Y., Cao, Z., Shang, Y., Wang, X. L., Peng, C. C., Yu, X. C., Zhu, S. Y., Fan, R. C., Xu, Y. H. and Zhang, D. P. 2006. The Mg-chelatase $\mathrm{H}$ subunit is an abscisic acid receptor. Nature 443, 823-826.

75. Sirichandra, C., Davanture, M., Turk, B. E., Zivy, M., Valot, B., Leung, J. and Merlot, S. 2010. The Arabidopsis ABA-activated kinase OST1 phosphorylates the bZIP transcription factor ABF3 and creates a 14-3-3 binding site involved in its turnover. PLOS One 5, e13935.

76. Stone, S. L., Hauksdóttir, H., Troy, A., Herschleb, J., Kraft, E. and Callis, J. 2005. Functional analysis of the RING-type ubiquitin ligase family of Arabidopsis. Plant Physiol 137,
13-30.

77. Stone, S. L., Williams, L. A., Farmer, L. M., Vierstra, R. D. and Callis, J. 2006. KEEP ON GOING, a RING E3 ligase essential for Arabidopsis growth and development, is involved in abscisic acid signaling. Plant Cell 18, 3415-3428.

78. Suzuki, M., Kao, C. Y. and McCarty, D. R. 1997. The conserved B3 domain of VIVIPAROUS1 has a cooperative DNA binding activity. Plant Cell 9, 799-807.

79. Uno, Y., Furihata, T., Abe, H., Yoshida, R., Shinozaki, K. and Yamaguchi-Shinozaki, K. 2000. Arabidopsis basic leucine zipper transcription factors involved in an abscisic acid-dependent signal transduction pathway under drought and high-salinity conditions. Proc Natl Acad Sci USA 97, 1163211637. $\mathrm{T}$

80. Umezawa, T., Nakashima, K., Miyakawa,., Kuromori, T., Tanokura, M., Shinozaki, K. and Yamaguchi-Shinozaki, K. 2010. Molecular basis of the core regulatory network in ABA responses: sensing, signaling and transport. Plant Cell Physiol 51, 1821-1839.

81. Umezawa, T., Sugiyama, N., Mizoguchi, M., Hayashi, S., Myouga, F., Yamaguchi-Shinozaki, K., Ishihama, Y., Hirayama, T. and Shinozaki, K. 2009. Type 2C protein phosphatases directly regulate abscisic acid-activated protein kinases in Arabidopsis. Proc Natl Acad Sci USA 106, 1758817593.

82. Vahisalu, T., Kollist, H., Wang, Y. F., Nishimura, N., Chan, W. Y., Valerio, G., Lamminmäki, A., Brosché, M., Moldau, H., Desikan, R., Schroeder, J. I. and Kangasjärvi, J. 2008. SLAC1 is required for plant guard cells S-type anion channel function in stomatal signalling. Nature 452, 487-491.

83. Wu, F. Q., Xin, Q., Cao, Z., Liu, Z. Q., Du, S. Y., Mei, C., Zhao, C. X., Wang, X. F., Shang, Y., Jiang, T., Zhang. X. F., Yan, L., Zhao, R., Cui, Z. N., Liu, R., Sun, H. L., Yang, X. L., Su, Z. and Zhang, D. P. 2009. The magnesium-chelatase $\mathrm{H}$ subunit binds abscisic acid and functions in abscisic acid signaling: new evidence in Arabidopsis. Plant Physiol 150, 1940-1954

84. Yin, P., Fan, H., Hao, Q., Yuan, X., Wu, D., Pang, Y., Yan, C., Li, W., Wang, J. and Yan, N. 2009. Structural insights into the mechanism of abscisic acid signaling by PYL proteins. Nat Struct Mol Biol 16, 1230-1236.

85. Yoshida, R., Hobo, T., Ichimura, K., Mizuguchi, T., Takahashi, F., Alonso, J., Ecker, J. R. and Shinozaki, K. 2002. ABA-activated SnRK2 protein kinase is required for dehydration stress signaling in Arabidopsis. Plant Cell Physiol 43, 1473-1483.

86. Yoshida, R., Umezawa, T., Mizoguchi, T., Takahashi, S., Takahashi, F. and Shinozaki, K. 2006. The regulatory domain of SRK2E/OST1/SnRK2.6 interacts with ABI1 and integrates abscisic acid (ABA) and osmotic stress signals controlling stomatal closure in Arabidopsis. J Biol Chem 281, 5310-5318.

87. Yoshida, T., Nishimura, N., Kitahata, N., Kuromori, T., Ito, T., Asami, T., Shinozaki, K. and Hirayama, T. 2006. ABA-Hypersensitive Germination3 encodes a protein phosphatase $2 \mathrm{C}$ (AtPP2CA) that strongly regulates abscisic acid 
signaling during germination among Arabidopsis protein phosphatase 2Cs. Plant Physiol 140, 115-126.

88. Yoshida, T., Fujita, Y., Sayama, H., Kidokoro, S., Maruyama, K., Mizoi, J., Shinozaki, K. and Yamaguchi-Shinozaki, K. 2010. AREB1, AREB2, and ABF3 are master transcription factors that cooperatively regulate ABRE-dependent ABA signaling involved in drought stress tolerance and require ABA for full activation. Plant $J 61,672-685$.

89. Zhang, D. P., Wu, Z. Y., Li, X. Y. and Zhao, Z. X. 2002. Purification and identification of a 42-kilodalton abscisic acid-specific-binding protein from epidermis of broad bean leaves. Plant Physiol 128, 714-725.

90. Zhang, X., Garreton, V. and Chua, N. H. 2005. The AIP2 E3 ligase acts as a novel negative regulator of ABA signaling by promoting ABI3 degradation. Genes Dev 19, 1532-1543.
91. Zhang, Y., Feng, S., Chen, F., Chen, H., Wang, J., McCall, C., Xiong, Y. and Deng, X. W. 2008. Arabidopsis DDB1-CUL4 ASSOCIATED FACTOR1 forms a nuclear E3 ubiquitin ligase with DDB1 and CUL4 that is involved in multiple plant developmental processes. Plant Cell 20, 1437-1455.

92. Zhang, Y., Yang, C., Li, Y., Zheng, N., Chen, H., Zhao, Q., Gao, T., Guo, H. and Xie, Q. 2007. SDIR1 is a RING finger E3 ligase that positively regulates stress-responsive abscisic acid signaling in Arabidopsis. Plant Cell 19, 1912-1929.

93. Zhu, S. Y., Yu, X. C., Wang, X. J., Zhao, R., Li, Y., Fan, R. C., Shang, Y., Du, S. Y., Wang, X. F., Wu, F. Q., Xu, Y. H., Zhang, X. Y. and Zhang, D. P. 2007. Two calcium- dependent protein kinases, CPK4 and CPK11, regulate abscisic acid signal transduction in Arabidopsis. Plant Cell 19, 30193036.

초록 : 식물의 앱시스산 신호 전달 기작: 앱시스산 수송, 인식, 신호 전달 및 번역 후 변형 과정에 관하여 이재훈*

(부산대학교 사범대학 생물교육과)

식물의 생활사 동안 물부족 스트레스는 식물의 생장과 발달에 해로운 영향을 끼치는 대표적인 스트레스이다. 유용 작물의 생산성을 증가시키기 위하여, 물부족 스트레스를 극복하는 일은 식물학 연구 분야에서 가장 중요한 이슈로 대두되어 왔다. 식물의 호르몬 중에서 앱시스산은 물부족 스트레스에 대해 식물이 저항성을 나타내는데 가장 중요한 호르몬으로서 역할을 수행하며, 씨앗의 발아, 기공의 개폐, 유묘의 성장과 같은 다양한 발달 과정에도 관여하고 있다. 그러므로, 앱시스산에 의해 매개되는 식물의 신호전달 기작을 명확히 이해하는 것은 물부족 스트 레스에 대한 내성을 갖는 유용 식물을 생산해내기 위해 가장 효과적인 방법이 될 것이다. 한편, 인산화, 유비퀴틴 화와 같은 번역 후 변형 과정은 식물이 다양한 환경적 스트레스 하에서 신속하게 적응을 하기 위해 가장 효율적인 기작으로 인식되어 왔는데, 이는 전사수준에서의 조절과 달리 이미 존재하는 신호전달 물질의 활성과 안정성을 직접적으로 빠르게 조절할 수 있기 때문이다. 본 총설에서는 앱시스산의 신호전달 과정과 관련된 최근 연구 동향 을 업데이트하고자 하며, 특히 이러한 신호전달 과정을 앱시스산 수송, 인식, 신호전달 및 번역 후 변형 과정에 초점을 맞추어 알아보고자 한다. 또한 그러한 조절 기작이 농업분야에서 유용 작물을 생산하는데 어떻게 적용될 수 있는지에 대한 향후 전망에 대해서도 기술하고자 한다. 